\title{
Broadband Internet Development and Economic Growth: A Comparative Study of Two Asian Countries
}

\author{
Amir Manzoor \\ (Bahria University, Karachi Campus, Management Sciences Department)
}

\begin{abstract}
The rapid evolution of telecommunication, World Wide Web, and computing technologies continues to shape the businesses around the globe. In this rapidly changing technological environment, a country's broadband Internet readiness has become a significant factor of the global competitiveness of a nation. Using a modified Porter's diamond model, this study compares broadband Internet development in Pakistan and India and investigates various factors that contributed to the different degrees of broadband Internet development in the two countries. The study finds that the diffusion of broadband Internet does contribute to the global competitiveness of a nation. The study reports findings from the first comparative study of Pakistan and India carried out in the area of broadband Internet competitive advantage.
\end{abstract}

Keywords - adoption, broadband, consumer, diamond model, Internet

\section{Introduction}

The current development of the broadband Internet access market varies greatly across different countries. Broadband Internet penetration rates and share of different broadband access technologies also varies around the globe. Broadband Internet continues to influence every aspect of life including businesses. Businesses as well as national economies are increasingly dependent on broadband Internet for their efficient and effective functioning. The rapid deployment of broadband Infrastructure around the globe is altering the nature of many businesses. It is also changing the nature of a variety of services and content delivered through conventional and non-conventional (such as Internet) channels [(Wolf \& Zee, 2000). (Rao, 2001)]. Increasing broadband Internet access has provided many new business opportunities and providing a wide variety of applications from streaming media to tele-medicine (CNETNews, 2002). Due to its ability of global reach, Internet is changing the fundamental nature of global business by providing people opportunity to connect to other people and businesses with no time or geographical limitations [(Sprano\&Zakak, 2000), (Albert \&Flournoy, 2010)]. In essence, the country-readiness of broadband Internet affects its national competitive advantage.

How a country leads in the development of broadband Internet is a critical question for national competitiveness. Comparative advanced deployment of broadband Internet in India and Pakistan makes them an important case for assessing the possible environmental factors that have contributed to broadband achievement through a comparison of the two countries. This study assess the current status of broadband Internet in two countries, discusses the role of broadband Internet in nation's competitive advantage at global level and then apply a modified Porter's diamond model(C. Lee \& Chan-Olmsted, 2004) to provide a comparison of broadband-related environmental factors in India and Pakistan.

The study consists of eight sections. The introduction section provides the structure and organization of the study. After the introduction section, section two provides a literature review. Section three provides the research questions investigated in the study. Section four discusses the research methodology and data collection strategies employed. Following research methodology, the results of the study are discussed in section five. Section six provides discussion of the results of the study. Following this discussion, the section seven provides research implications. The section eight at the end discusses limitations of the study and further research avenues.

\section{Literature Review}

Assessment of differential development of broadband Internet in India and Pakistan requires a review of various factors that might affect the national level growth of broadband Internet and the relationship between broadband Internet and the global competitiveness of a nation. 


\subsection{Factors Influencing the Development of the Internet}

There exist many country-level broadband Internet (or Internet) studies. Analyzing seven developed countries, (Garfield \& Watson, 1997)found a significant role of national culture in the policy decisions and development of country-level information infrastructures. Comparing the adoption processes of the broadband access in the United States and Korea, (Han, 2003) found that the combination of government's ICT policy and the unique cultural traits was the driving force behind the rapid diffusion of the broadband access. Examining the factors that encourage Internet diffusion across OECD countries, (Hargittai, 1999)established that the most significant predictors of country-level Internet uptake were the country's economic wealth and telecommunications policy.[(OECD, 2001a), (OECD, 2008)] found that infrastructure competition and removing differences in broadband Internet access was the most viable factor governments could use for the faster broadband Internet uptake. It also emphasized the importance of more competitive environment for the dominant broadband market leaders (through policies such as local loop unbundling and line sharing) as secondary necessary step to boost broadband Internet diffusion.

The studies cited, however, focused on individual factors responsible for the growth of broadband Internet (or Internet) growth. Most studies investigating the link between country's competitive advantage and growth in various broadband-related industrial sectors have compared United States with many Asian countries for example (H. Lee et al., 2003) and (Choudrie\& Lee, 2004). Taking Singapore as a success story of a most comprehensive and coordinated effort to promote information technology, (Hon, 1992) suggests that a proactive government strategy is the driving force behind the successful Internet deployment. Specifically the government policies regarding funding for small and medium-sized information technology companies, adoption of global standards, special demonstration projects, and skills development are key to the Internet development at country level. While the developed countries already established policies to promote IT innovation, the process of institutionalization of policies to accelerate and support IT innovation started in various newly industrialized and developing nations(King et al., 1994). Investigating broadband development in South Korea, (Choudrie\& Lee, 2004) identified government leadership, fierce competition, low prices, cultural aspects, and geographic and demographic aspects as the driving factors behind broadband internet growth. Analyzing developed OECD nations, (Cane, 1992) argues that managerial and regulatory obstacles tend to inhibit diffusion of information technology despite the availability of well-built infrastructures, computer and telecom industries, and significant resources. Investigating the patterns and problems of Internet diffusion in less developed countries, (Goodman, Press, Ruth, \&Rutkowski, 1994) suggested three barriers to the wider distribution of Internet: government policies, laws, and practices; technical barriers; and local/cultural factors.

Many analytical frameworks have been developed to understand Internet roll out and use at country level. Analyzing low and middle-lower income countries ${ }^{1}$, (Bazar, 1997) suggested a framework to assess the Internet development at country level. This framework consisted of dimensions such as government policies, national culture, country-wide information technology penetration, economic development, and national language. Analyzing in-depth studies of about 25 countries undertaken since 1997, (Wolcott, Press, McHenry, Goodman, \& Foster, 2001) suggested a framework for assessing Internet diffusion at country level. This framework consists of six dimensions and 12 determinants, divided into three categories, which influence these dimensions. The six dimensions include sectoral absorption, organizational infrastructure, geographic dispersion, sophistication of use, pervasiveness, and connectivity infrastructure. The 12 determinants include variety of ISPs, Geography, Cost of Internet access, Ease of use of the Internet, perceived value, demand for capacity, adequacy and fluidity of resources, Culture of entrepreneurship, ability to execute, forces for change, change enablers, and regulatory/legal framework.(Beilock \& Dimitrova, 2003) suggested that the Internet development at country level is most significantly influenced by per capita income. The two other influencing factors include openness of a society and infrastructure. Analyzing African least-developed economies, (Mbarika\& Byrd, 2009)suggested six factors behind the Internet development at country level. These factors include domestic and foreign investment in ICT, wireless and satellite infrastructure, self-sufficiency, government regulatory policies, local capacity, and degree of privatization of telecommunications sector.

\subsection{Relationship between Broadband Internet Technology and Competitiveness}

For a nation's economic prosperity, broadband Internet infrastructure has become strategically important with the emergence of electronic commerce [(Garfield \& Watson, 1997), (Oxley \&Yeung, 2001), (H. Lee, O'Keefe, \& Yun, 2003), (Greenstein \& Prince, 2006),(Turk, JermanBlažič, \&Trkman, 2008),(Czernich,

${ }^{1}$ Such as China, Vietnam, Mongolia, Laos, Philippines, India, and most African countries 
Falck, Kretschmer, \&Woessmann, 2011)]. With migration towards a heavily e-commerce dependent-economy, the future contribution of Internet to the nation's economic wealth will be increasingly significant [(Garfield \& Watson, 1997),(Oxley \&Yeung, 2001)]. (Schumpeter, 1947) idea of technological competition in capitalist economies became the basis of 1960s neo-technological trade theories. According to (Dosi, Pavitt, \&Soete, 1990), these theories signified the impact on trade of differential cross-country technological competency. Analyzing 15 OECD countries data of two decades (1960-1980),(Fagerberg, 1988) found that increasing technological ability and productive capacity is important for competitiveness of a nation. Broadband plays a critical role in the functioning of national economy, the social interaction, and facilitates connection among businesses, governments, and consumers(OECD, 2008). In essence, the previous studies establish the importance of broadband Internet readiness for a nation's global competitiveness.

\subsection{Porter's Diamond Model}

Porter's diamond model (Porter, 1990a) is an analytical framework that can be used to study the sources of an industry's competitive advantage while taking into consideration the country-level factors. The diamond model has four country-based analytic dimensions. These four dimensions are industry factors, demand conditions, supporting industries, and firm context and strategy. The degree of interaction among the four dimensions determines the magnitude of national success. Many researchers have criticized diamond model e.g. about its ability to provide precise definitions of some key concepts and the predictive ability(Grant, 2006), difficulty in identifying causal relationships(Kaufman, Gittell, Merenda, Naumes, \& Wood, 1994), and applicability of the model in small economies ${ }^{2}$ [(Rugman\& Alan, 1992), (Bellak\& Weiss, 1993),(Rugman\&D'Cruz, 1993),(Cartwright, 1993),(O’Donnellan, 1994),(Moon, Rugman, \&Verbeke, 1995), (O’Malley \& O'Gorman, 2001), (Öz, 2002), (Sohn, 2004)].

However, there exist many studies that employed Porter diamond model to examine various industries e.g. to determine British local economy's competitiveness (Healey \& Dunham, 1994), to evaluate research performance of various departments of higher education institutions in UK(Curran, 2001), to assess competitiveness of Armenia(Chobanyan\& Leigh, 2006), to explore the development of competitive advantage of Irish software industry(O'Malley \& O'Gorman, 2001), to investigate Taiwan's TFT-LCD industry competitive advantage(Chang, 2005), to investigate competitive advantage of Silicon Valley of USA [(Wonglimpiyarat, 2005),(Wonglimpiyarat, 2006)], and to investigate the competitive advantage of Chinese automobile industry $(\mathrm{Wu}, 2006)$. The studies found that causes of competitive advantage of an industry can be found in all four of Porter's suggested determinants of competitive advantage.

Traditionally, governments have applied push strategy to promote and develop information and communication technology infrastructure by providing the right environment. Increasingly, the governments will need to switch their focus to pull strategy of Internet development by promoting digital literacy, establishing an enabling environment, and fostering the development of applications, including local content (Williams, Kelly, Mulas, Zhen-Wei Qiang, \& Raja, 2010).(Picot \& Wernick, 2007) concluded that successful governmental strategies include both public good and competition-related aspects of broadband.

\section{Research Questions}

The broadband Internet deployment levels vary in Pakistan and India. This study will apply Porter' Diamond Framework to compare various environmental factors related to broadband Internet in both countries to assess national competitive advantage. The factors included in the study will be those that probably influence the Internet growth in a country and affect the relationship between technology and the competitiveness of a nation at global level.

\section{Research Methodology And Data Collection}

To investigate the research questions, a case study approach will be used in this study with selected cases being Pakistan and India. The case study approach is suitable for the topics that involve special or unique situations requiring intensive, in-depth, study [(Bradshaw \& Wallace, 1991),(R. K. Yin, 1992),(Winston Tellis, 1997),(D. R. K. Yin, 2002), ,(Gomm, Hammersley, \& Foster, 2000), (Dul\&Hak, 2007)] as is the current study of India and Pakistan.

\footnotetext{
${ }^{2}$ such as Ireland and Finland
} 
This study will use a modified Porter diamond model suggested by (C. Lee \& Chan-Olmsted, 2004)for the comparative study of the broadband Internet markets of both countries (See figure 1). The modified diamond model includes government as a significant external determinant of competitiveness. The inclusion of this determinant is necessary because of two reasons. First, the government has the ability to support and encourage an entrepreneurial environment and infrastructure (O'Shaughnessy, 1996). Second, changes in regulatory establishment require corresponding changes in any one or all the determinants of Porter's diamond and their associated strategies (Beije \& Nuys, 1995). The determinant of government may influence other determinants and at the same time be influenced by each of the four diamond determinants. The modified diamond model will use industry, not the firm, as unit of analysis. This is because the firms innovate to survive under competition and competition has a positive link with increased improvement and innovation (Porter, 1990a). Subsequently, the determinant of firm strategy, structure, and rivalry will be changed to Competition Conditions determinant. An industry-level competition conditions determinant probably is a more appropriate choice for this study. Therefore, the competitive advantage of nation can be considered as function of five determinants: Advanced Factor Conditions, Consumer/Demand Conditions, Related and Supporting Industries, Competition Conditions, and Government.(Beije \& Nuys, 1995) found that Advanced Factor Conditions (such as facilities for research, educational levels, and communication networks) are most significant in determining industry dynamics and to achieve higher levels of competitive advantage.

\subsection{Measures of Proposed Determinants of Diamond Model}

Limited studies are available that focus on Internet or electronic commerce development at global level [(Bazar, 1997), (Hargittai, 1999) ,(Sprano\&Zakak, 2000), (Guillén\&Suárez, 2001),(OECD, 2001a),(Oxley \&Yeung, 2001), (Wolcott et al., 2001), (Wunnava\&Leiter, 2009)]. With limited available literature the task of developing feasible measures of the determinants of diamond model is fairly challenging.

\subsection{Advanced Factor Conditions}

National Internet infrastructure, the educated and skilled labor force, and number of research institutes are measures that can be used to represent advanced factor conditions (Porter, 1990a). Internet infrastructure can be measured by measuring the household PC penetration level ${ }^{3}$, the ratio/number of broadband Internet connections among total Internet users, the number of World Wide Web hosts, and the number of web sites. The number of people accessing Internet using broadband Internet is an indicator that can be used to measure both the potential of e-commerce and extent of access to a wide array of online services. The number of Internet hosts can be used as an indicator to measure Internet infrastructure development (Atkinson \& Court, 1998).

The number of Internet web sites is an indicator that can be to represent the level of Internet content development at national level (OECD, 2001b). The education level completed by adults is a useful indicator that can be used as a reflection of a person's skill level and measure level of the human resource(OECD, 2001c).

\subsection{Consumer/Demand Conditions}

The determinant of consumer/demand conditions denotes two aspects of consumers' demand: quality and quantity(Porter, 1990a). To understand the consumer demand of broadband Internet, this study will utilize as proxy the Internet consumers' characteristics and behavior. To understand Internet consumer characteristics, demographic factors ${ }^{4}$ will be reviewed. To gain understanding of the behavior of Internet consumers, their common online activities are studies. To understand behavior of potential Internet consumers, the reasons for non-connectivity to the Internet are also assessed.

\subsection{Related and Supporting Industries}

For this determinant, the study will focus on e-commerce which is an essential Internet-driven industry. (Sprano\&Zakak, 2000) found that E-commerce, with efficiencies gained through used of Internet technologies, can help gear up or shift national competitiveness. The number of secure servers in a country is an approximate and reasonable measure of national e-commerce activities(OECD, 2001b). Number of e-commerce transactions is an indicator that can be used to measure the volume (or size) of e-commerce business in a country [(OECD, 2002),(US Census Bureau, 2001)].

\footnotetext{
${ }^{3}$ A computer is a necessary requirement for Internet connectivity.

${ }^{4}$ E.g. level of income, education level, and age
} 


\subsection{Competition Conditions}

For this determinant, the study will focus on competition in broadband Internet industry ${ }^{5}$. (OECD, 2001c) found that this competition was one of the significant factors affecting the growth of Internet development in certain countries. The study will review competition among technologies (such as (Digital Subscriber Line) (DSL), cable mode, wireless etc.) and the competition among broadband Internet service providers. To examine the competition in the market, the study will examine the pattern of broadband Internet market share of competing technologies and the top-four firms' ratios (CR4). To evaluate the results of competition, the study will also review the price of broadband Internet access.

\subsection{Government}

For this determinant, the study will examine broadband-related specific government policies and the regulatory regimes of telecommunication operators to evaluate the differential governmental influence on broadband Internet market.

For the purpose of this study, various sources such as government publications, marketing research reports, and press reports were studied. Specific data sources include OECD, World Bank, UNDP Statistics, UNESCO Statistics, International Telecommunication Union (ITU), government sources etc. were used.

\subsection{Role of the Government}

\section{RESULTS}

\subsubsection{Pakistan}

First broadband connection in Pakistan was given in 2002. The projected number of broadband subscribers in Pakistan by 2009 was 643,892 and it was expected that the number will reach 1,213,000 by 2012 (PTA, 2011).Since Pakistan Telecommunication Authority (PTA), the telecom regulatory authority in Pakistan, enforced the deregulation policies including giving broadband licenses to private companies in 2004, many players entered into the broadband market. There were players competed in providing broadband with same technologies and there were players who dominated in particular access technology. Fixed line penetration was a significant issue in Pakistan. Fixed line penetration rate was 3.5\% in 2009 and it was expected to drop to 2.8\% by 201. During the last decade, Pakistan saw sustained growth in its telecom industry (especially the mobile sector). During 2006-2007, the total mobile phone subscribers increased from 22 million to 77 million. Over the last few years, the Pakistan broadband Internet market witnessed a great deal of technological and strategic transformation. Competition in the broadband market strengthened after the introduction of a new operator Qubee (a Wireless-based broadband service provider). Soft licenses and relaxed terms and conditions from Pakistan Telecommunication Authority (PTA) facilitated access to latest broadband technologies in Pakistan. A wide range of broadband technologies (such as DSL, Worldwide Interoperability for Microwave Access (WiMAX), Fiber-to-the-Home (FTTH), Evolution-Data Optimized or Evolution-Data Only(EvDO), Hybrid fiber-coaxial(HFC)and Very-high-speed digital subscriber line 2( VDSL2)were made available to Pakistani Internet users (PTA, 2011).

Wateen, a UAE-based telecommunication company operating in Pakistan, launched World's first largest commercial WiMAX network in Pakistan in 2007. Pakistan Telecommunication Company Limited (PTCL) was the first telecom operator on the globe that used VDSL2 technology under brand name PTCL Ultra Net (with supported bandwidth of up to $50 \mathrm{Mbps}$ ). PTCL also deployed its first Fiber to Home service in Karachi which was based on Gigabit Passive Optical Network technology. Mobile Number Portability (MNP) project was launched in 2010 which further intensified competition in the market. Government of Pakistan established a Universal Service Fund (USF) to with the mandate of developing telecommunication services in both un-served and under-served areas of Pakistan. The funds for USF operation were contributed by telecom Operators and government provided no funding. An independent board of directors, with members from industry and consumers, was setup to run the affairs of USF. Significant contributions of USF included providing 300,000 new broadband connections and establishing more than 800 Educational Broadband Centers in different higher-secondary schools/colleges and more than 200 Community Broadband Centers in USF areas.

\footnotetext{
$\overline{{ }^{5} \text { E.g. competition among different networks, technologies, and companies }}$
} 


\subsubsection{India}

First broadband connection in India was given in 1998. The projected number of broadband subscribers in India by 2007 was 9 million and it was expected that the number will cross 15 million by 2012. The Indian government announced its broadband policy in 2004. After the Broadband policy was unveiled in 2004, Operators such as VSNL Broadband Limited and Reliance Communications Limited established strong fiber optic backbones. India is considered as one of the largest and fastest growing major telecom markets in the world. Broadband Internet in India is growing mainly due to the rapid growth in Indian telecommunication sector. India's growing economy, rapidly expanding middle class, low tariffs, and highly competitive market have further supported the continuous expansion of the broadband sector(ABI Research, 2012).Successive Indian governments introduced comprehensive reforms over the last decade that changed the landscape of telecommunication in India. Indian government has taken many initiatives, such as Indian PC program, egovernance, e-learning, and e-healthcare services, to spur the growth of broadband Internet. Broadband network expansion and upgrades are underway in India to match up with comparable Asian broadband markets. Indian government has made three priorities for their future plans to increase broadband penetration and usage: lower CPE pricing, affordable broadband software and hardware, and cheap, consistent broadband interconnectivity among villages (Informationweek, 2011).

The Indian government has continued its policy of an open and competitive broadband market. Some of the key steps in this regard included issuing licenses to new telecom operators, allowing global operators to work with local companies, privatization of the country's long-distance market, bandwidth sharing among ISPs, allowing the use of Ku-band in both Indian and foreign satellites, and launch of Mobile Number Portability (MNP)(TRAI, 2010).In 2011, the fixed line penetration in India was 3\% and around 98\% of the Indian population had some form of access to a telephone (BusinessWire.com, 2011). During the last decade heavy investment was made in telecom infrastructure. The Indian government continued to force completion of restructuring of telecommunications regulatory regime. The Telecom Regulatory Authority of India (TRAI) continued its structural reforms such as adoption of unified licensing, increased infrastructure sharing, and revised foreign direct investment policy increasing foreign ownership limit from $49 \%$ to $74 \%$ (TimesofIndia, 2012). In 2012, Indian government approved a national broadband plan. The objective of the plan was to provide high-speed Internet access and e-government services to more than 160 million people by 2014. Under this plan, an open access country-wide optical-fiber based broadband network will be established which will provide connectivity to all areas with population of 500 and above by 2013(TRAI, 2010).

\subsection{Determinant Comparison}

\subsubsection{Comparing the Advanced Factors}

The comparison of advanced factors conditions is performed with respect to broadband Internet infrastructure and the educated and skilled labor force.

\subsubsection{Broadband Internet infrastructure}

Pakistan lags behind India in terms of the PC penetration and broadband connections. The personal computers per 100 people in Pakistan were 0.4 while in India it was 3.3 (See TABLE 1). The number of fixed broadband Internet subscribers per 100 people in Pakistan was 0.37 while in India it was 0.67 . With respect to the relative number of hosts and Web sites, Pakistan is far behind India with 0.65 hosts per 1000 inhabitants. India has a large number of Websites exists in national and other languages (20,000 and 130,000 respectively). While the same data for Pakistan was not exactly available, industry experts believe that the situation is very dismal. This situation depicts that the Pakistan has produced much less online content than India.

In summary, Pakistan lags behind India with respect to the PC penetration and households with broadband Internet access. Thus, Pakistan appears to forgo the potential advantage of network externalities. Pakistan has much less concentration of Internet hosts and Web sites, which is a disadvantage for the production of Internet content. In summary, Pakistan's Factor Conditions have focused on the consumption of Internet content with little or no emphasis on production of Internet content. 


\subsubsection{Educated/skilled labor force}

Pakistan lags behind India with respect to the educated labor force. The overall literacy rate in Pakistan was $56 \%$ compared with $63 \%$ in India. About $1.51 \%$ of the Pakistani population aged 25-64 years completed university level education, compared to $4.57 \%$ for India. In Pakistan, there were 64 technicians per million people compared to 94 in India. There were approximately 152 researchers per million people in Pakistan compared with 137 in India. (See TABLE 1)

Pakistan appears to have an overall less educated labor force than India. Since an educated and skilled labor force often represents the extent of national investment in knowledge creation, we can safely conclude that the Pakistani nation has invested less in knowledge creation than India. Comparatively, India seems in a better position to become a knowledge-based economy.

\subsubsection{Comparison of the Nature of Internet Consumers}

This section reviews key characteristics of demographic profile and the main activities of broadband Internet users in Pakistan and India. The reasons for non-connectivity of people are also discovered to understand behavior of potential Internet users.

\subsubsection{Education}

In Pakistan, approximately 37\% of the Internet population had a bachelor's degree and 63\% completed high-school compared with $44 \% \%$ and $49 \%$ of Internet population in India respectively. In summary, compared with India, Pakistan exhibits a greater degree of inequality of Internet use between high-level education and low-level education Internet users. (See TABLE 3)

\subsubsection{Age/Gender}

With respect to age, Pakistani and Indian Internet users share somewhat similar profile. Internet users had a significant proportion of teenagers and university students than people aged 45 and more. Internet usage in Pakistan is growing rapidly especially among students and metropolis. There appears to be a relatively large gap between the young and older Internet users in Pakistan than India. Similarly, more man than woman using Internet in Pakistan as in the case of India. In summary, the inequality of Internet use between younger and older Internet users is greater in Pakistan than India.

\subsubsection{Family Income}

High-income Pakistani individuals were more likely to be Internet users as compared with their Indian counterparts. Internet use by high-income households was 5\% in India and 75\% in Pakistan. In contrast, Internet use by middle-income households was around $89 \%$ in India and $14 \%$ in Pakistan (See TABLE 3). It appears that the difference of Internet use between different income groups is relatively smaller in Pakistan than India.

\subsubsection{Housing Pattern}

The Internet users in both Pakistan and India share a similar geographical pattern. Both countries had more urban Internet users than rural users. The broadband Internet penetration rate among Indian urban households was 95\% and 96\% in Pakistan (See TABLE 3). There exists a large inequality of Internet use between urban and rural households in both countries.

Internet users in Pakistan and India seem share similar demographic profile characteristics i.e. more users had higher education, young age, middle income, male, and lived in urban settings. In summary, the widespread use of the Internet in both countries appears to be more concentrated in specific consumer groups.

\subsubsection{Main Online Activities}

Internet users in Pakistan and India exhibit slightly different preferences with respect to online activities. The primary online activities of Pakistani Internet users were information search (Financial, educational, general), e-mail, playing online games, and Entertainment (Music, Videos). On the other hand, primary online activities of Indian Internet users were e-mail, entertainment (Music, Videos), Information 
Search (Financial, educational, general), and text chat (See TABLE 4). It appears that Internet users of both Pakistan and India share some common online activities such as information search, e-mail, and entertainment. Yet, Indian users appear to involve more in entertainment activities (such as music, videos, and games). A possible explanation of this phenomenon could be that Indian broadband Internet environment is more developed and a larger proportion Internet users is of young age.

\subsubsection{Reasons for Not Using the Internet}

People who do not use Internet in Pakistan cite similar reasons compared with their Indian counterparts, but with varying degree of importance attached to each reason. Chief reasons for Pakistani users not using the Internet at home include "No awareness of Internet," "No need of Internet", "access elsewhere", "don't have PC know-how", "don't have PC", "concern with children", "improper electricity supply", and "unaffordable" in that order(See TABLE 4). Comparatively, unawareness of Internet and no need of Internet may be more significant issues influencing the rate of broadband Internet growth in Pakistan and India.

\subsubsection{Comparison of Related/Supported Industries: E-commerce}

The likely activities of Internet users also include some specific activities that facilitate the growth of other industries such as e-commerce. Gartner group predicted that in 2005, Asian and Pacific region will account for $28 \%$ of world B2B E-commerce transactions which itself will grow to US\$2.4 trillion. The global B2B e-commerce transactions reached US\$ 12.4 trillion in 2011 as compared with US\$ 3.4 trillion in 2005. Another advantage of E-commerce is its transaction efficiency and cost savings. For example a banking transaction over the internet costs just $1 \%$ of an over-the-counter transaction at a branch (The Economist, 2009).

There exists disparity in e-commerce development between Pakistan and India. Pakistan had 1 secure servers per million inhabitants compared with 2 secured servers per million inhabitants in India (See TABLE 1). India is well ahead of Pakistan with respect to the overall volume and development of e-commerce. In December 2010, the total e-commerce transactions of India were 31598crore Indian rupees(Bimal Anjum \& Rajesh Tiwari, 2011). Though exact figures are not available, arguably, in Pakistan, E-commerce is almost nonexistent compared with the e-commerce transactions in the India. In India, B2B transactions dominated ecommerce transaction ( $92 \%$ of total e-commerce transaction). Though no exact figure available, arguably, the Pakistani Internet users inclined more to consume online content than to participate in online transactions. On the other hand, the low number of Internet secure servers and volume of online business transactions in Pakistan depicts significant shortage of online content and economic activities.

\subsubsection{Comparison of Market Competition}

This section provides a review of competition between technologies (DSL, WiMAX etc.) and competition among companies in Pakistan and in India. Competition is assessed through the market share of different technologies, the ratio (CR4) of broadband Internet market's top-four firms, and the tariff of broadband Internet access service.

\subsubsection{Growth of the Broadband Internet}

The number of broadband Internet subscribers increased from 1997 to 2011 in both Pakistan and India. Pakistan reveals much lower growth rates compared to India. Internet use at home grew at a rate of 3\% in Pakistan while in India the growth rate was $35 \%$. Besides other factors, relative lack of competition and low $R \& D$ in broadband appears to be significant factors behind this Pakistani broadband market growth despite the fact the number of broadband Internet providers increased significantly from 1999 to 2011.

5.2.4.2 Competition between Distribution Technologies

Pakistan and India differ with respect to trends in broadband access technologies. In Pakistan, Wireless broadband is leading with a market share of 50.5\%. In India, fixed broadband is outpacing Wireless broadband with a market share of $93 \%$. Wireless is taking pace and will grow keeping in view there is no comprehensive wired communication infrastructure in place in India today.

Differences among housing patterns, tele-density, regulatory dissimilarity, and government prioritization of ICT may have contributed to the different degrees of development of fixed and wireless 
broadband in both countries. The relatively low cost of building the local exchange in Pakistan ${ }^{6}$ may have been helpful in dealing with distance limitation of fixed broadband technologies (such as DSL) but low tele-density is still a big issue.

The dominance of wireless in Pakistan might also be explained by the lack of telecommunication infrastructure and heavy deployment of Wi-max as an alternative to provide broadband access. In 2006, Motorola announced that Pakistan planned to roll out the world largest Wi-max network (CnetNews, 2006).

\subsubsection{Competition between Broadband Internet Firms}

Both Pakistan and India have relatively concentrated broadband Internet markets. The broadband Internet markets in both Pakistan and India reveals a 2-waycompetition between state-owned telecommunication company and the private ISPs.

In Pakistan, the competition is between state-owned PTCL and the private ISPs. PTCL share of the broadband Internet market was $57 \%$ in 2011. Wateen, the second-largest broadband service provider, had $15 \%$ of the market share. The other two significant players were Worldcall (10\% market share) and Qubee (9\% market share). Consequently, the CR4 ratio of the Pakistani broadband Internet market has been quite high: $91 \%$ in 2011. (See TABLE 6).

In India, state-owned BSNL share of the broadband Internet market was around $57 \%$ in 2011. MTNL, the second-largest broadband service provider, had $13.2 \%$ of the market share. The other two significant players were Bharti Airtel (10.22\% market share) and Reliance (7.72\% market share). Consequently, the CR4 ratio of the Indian broadband market has been quite high: $88 \%$ in 2011.

\subsubsection{Broadband Internet Pricing}

Beside other factors, the price of broadband Internet access is significantly influenced by degree of competition among the broadband access providers(OECD, 2001a). In Pakistanis broadband prices are relatively high in comparison with India. In Pakistan, the fixed broadband internet access tariff (in US\$ per month) was 15 while in India it was 5 (See TABLE 1). One possible explanation of this contradiction could be the large number of broadband subscribers in India and the difference in relative price elasticity of demand of Pakistani and Indian broadband Internet subscribers.

\section{Discussion Of Results}

The growth of broadband Internet in India and Pakistan seems to be swayed by multiple factors. First, the governments in both countries have played different roles to develop their broadband Internet markets. Indian government implemented several policies (e.g. liberalizing the telecommunication industry and promoting privatization in telecommunication sector) to speed up the development and growth of the broadband Internet. Indian government efforts appear to play a continued role to develop Indian national economy which is consistent with the previous research (Porter, 1990a).The Indian government policies are in line with many developing countries policies to introduce economic policies to accelerate IT innovation[(King et al., 1994),(Brown \& Thompson, 2011),(Gulati, Yates, \& Williams, 2012)]. In contrast, the Pakistani government has also implemented various regulatory reforms to promote competition, innovation, and private investment in the telecommunications sector. However, there was little emphasis on building national broadband Internet infrastructure. Consistent with the previous studies(Gao\&Rafiq, 2009), this approach, in general, has stimulated the development of broadband Internet services.

Comparing advanced factor conditions, we observe that Pakistan depicts somewhat different forms of strengths and weaknesses as compared to India. In Pakistan, the personal computer penetration rate, proportion of broadband Internet users, the number of World Wide Web hosts, and number of websites is low. In India, the penetration rate of personal computers, ratio of broadband Internet users, number of hosts, and number of websites are high. Two countries differ significantly with respect to highly educated labor force. It appears that the broadband Internet market in Pakistan appears to have developed with a focus online content consumption and broadband Internet market of India has focused on online content production. Consequently, Pakistan is not as strongly positioned to transform itself into a knowledge-based economy as India. Also, Pakistan doesn't have

\footnotetext{
${ }^{6}$ because the total area of Pakistan is much smaller than that of India
} 
advantage of network externalities in broadband Internet development. In other words, since Pakistan have less people connected to the Internet, the potential benefits from the network would be small and won't be sufficient to support the development of broadband Internet network services in Pakistan.

Comparing consumer demand conditions, we observe that broadband Internet has grown in Pakistan at a slower rate than India. Though Pakistan has a similar demographic profile of household broadband Internet users as compared to India, Pakistan reveals a widespread inequality among various demographic groups of broadband Internet users.

Pakistan may have a comparative disadvantage in broadband Internet, compared with India, in part due to the less developed broadband Internet related industries such as e-commerce. Pakistani e-commerce market is much smaller in size than that of India. According to (Oxley \&Yeung, 2001), the presence of an institutional environment that facilitates the transaction integrity is essential for the development of country-level ecommerce. (Seyal, Awais, Shamail, \& Abbas, 2004) pointed out that perceived benefits, task variety, organizational culture and government support were the significant predictors of e-commerce adoption by Pakistani among small and medium enterprises in Pakistan. Some points out that the perceived mistrust among the Pakistani Internet users about the e-commerce is a significant factor hindering the e-commerce development in Pakistan(Sulaiman\& Mohezar, 2007).

Competitive conditions appear to play a very significant role in broadband Internet expansion in Pakistan and India. According to (Porter, 1990a), creating and preserving competitive advantage in an industry has a strong empirical link with the intensity of domestic competition. India and Pakistan adopted similar broadband technologies. However, fixed broadband has dominated wireless broadband in India, while Wireless broadband continues to dominate fixed broadband in Pakistan. The housing pattern and regulatory environment has played a very important in dissimilar growth patterns of these technologies in Pakistan and India. The broadband Internet market of both Pakistan and is highly concentrated but Pakistan seems to have more local competition than the Indian broadband market.

The findings of this study provide important hints that affirm the positive impact of governmental broadband Internet policy on the development of a country's broadband Internet market. The Indian government's investment in the deployment of telecommunication infrastructure (including Optical-fiber networks) and early adoption of broadband Internet by urban users have impacted the supply and demand of broadband Internet services.

In essence, the Indian broadband Internet competitive advantage appears to be the active support of the Indian government and low prices of broadband Internet access. However, India still needs to work on improving the telecommunication infrastructure further and increase the PC penetration, and. To reap the economic benefits of increased broadband access is the next level of broadband Internet development. For this step, India needs to focus its attention to extend broadband Internet access to the rural population that could further strengthen the already growing and strong e-commerce market in India. India needs to work on reducing Internet access inequality and increase Internet literacy to ensure a continuous growth of broadband Internet demand and receive economic returns from this increased demand. Indian government needs to continue encouraging the development of alternative broadband technologies and extend its collaborative role in building major broadband network infrastructure to further accelerate the deployment of broadband Internet. In addition, information technology training and promotion programs are likely to speed up the development of knowledgebased economy which is an essential ingredient for the continued and successful growth of broadband Internet in India.

The active support of government also appears to be source of competitive advantage of broadband Internet in Pakistan. However, Pakistan still needs to work on improving the low penetration of computers and low broadband Internet penetration at home. In order to reap the economic benefits of broadband Internet deployment, Pakistan needs to focus its attention to increase skill base for production of online content, in addition to online content consumption, and building a strong e-commerce market. Pakistan and India share several drivers of broadband Internet. For example, continuation of policies encouraging alternative broadband technologies with an increased cooperative role of government and regulatory bodies in developing broadband infrastructure can also be helpful to speed up broadband Internet uptake in Pakistan. Similarly information technology training and promotion programs may be helpful in developing knowledge-based society and a skilled labor force. The knowledge and skilled labor force can in turn be helpful in addressing the problem of 
inequality of Internet use and Internet literacy. It can also ensure a continuous growth of broadband Internet demand and economic benefits for broadband Internet.

\section{Research Implications}

The evidence provided by this study has significant implications helpful for Broadband Internet Service Providers and policymakers seeking to encourage consumer adoption of broadband.

\section{Limitations Of Study And Further Research}

A main limitation of this study is the data which is not completely comparable by time periods and some data is unavailable. Results about interaction among the five determinants could be better achieved with more methodical and statistical analysis of an integrated data set. While this study focused on horizontal comparative development, future research may be longitudinal by taking into account other technologies and factors such as country's culture. Such research could provide a more comprehensive framework for a more objective assessment of broadband Internet development in country.

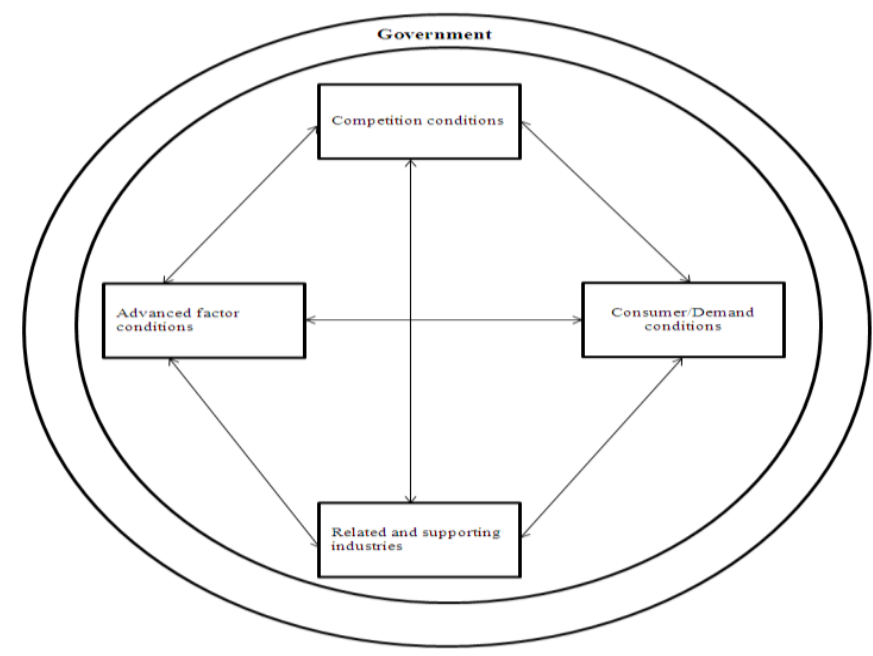

Figure 1: Modified Porter Diamond Model

Source: Porter (1990a) and (C. Lee \& Chan-Olmsted, 2004) 
Table 1: Comparison of Advanced Factor Conditions

\begin{tabular}{|l|l|l|}
\hline Indicator & $\begin{array}{l}\text { Pakistan (As of December } \\
2010)\end{array}$ & $\begin{array}{l}\text { India (As of December } \\
2010)\end{array}$ \\
\hline Personal computers per 100 people & 0.4 & 3.3 \\
\hline Internet users per 100 people & 12.0 & 5.3 \\
\hline $\begin{array}{l}\text { Fixed broadband Internet subscribers } \\
\text { per 100 people }\end{array}$ & 0.37 & 0.67 \\
\hline $\begin{array}{l}\text { International Internet bandwidth } \\
\text { bits per second per capita }\end{array}$ & 43 & 32 \\
\hline $\begin{array}{l}\text { Fixed broadband Internet access tariff } \\
\text { \$ per month }\end{array}$ & 15 & 5 \\
\hline $\begin{array}{l}\text { Secure Internet servers per million } \\
\text { People }\end{array}$ & 1 & 2 \\
\hline Estimated Web hosts per 1000 inhabitants & 0.65 & 1.54 \\
\hline Websites in National Language & Not available & 20,000 \\
\hline Websites in English + Other languages & Not available & 130,000 \\
\hline Technicians per million people & 64 & 94 \\
\hline $\begin{array}{l}\text { Percent of Population aged 25-64 completed university } \\
\text { level education }\end{array}$ & $1.51 \%$ & $4.57 \%$ \\
\hline Researchers per million people & 152 & 137 \\
\hline Level of competition: Internet Service Provider & $\mathrm{C}$ & $\mathrm{C}$ \\
\hline International Internet Bandwidth (bits per person) & 5 & 18 \\
\hline Government prioritization of ICT (Scale 1-7) & 4.45 & 5.53 \\
\hline Government Online Service Index (scale 0-1) & 0.25 & 0.37 \\
\hline Telephone lines (per 100 people) & 2.4 & 3.1 \\
\hline
\end{tabular}

Source: (World Bank, 2011a), (World Bank, 2011b), (UNDP, 2011), (World Economic Forum, 2011)

Table 2: Total Adult (Age 15 \& older) Literacy Rates (\%) (As of December 2010)

\begin{tabular}{|l|l|}
\hline Pakistan & India \\
\hline 56 & 63 \\
\hline
\end{tabular}

Source: (World Bank, 2011a)

Table 3: Internet users by demographic profiles

\begin{tabular}{|l|l|l|}
\hline Category & Pakistan(As of June 2011) & India(As of December 2010) \\
\hline Education & $63 \%$ & $44 \%$ \\
\hline High School & $37 \%$ & $49 \%$ \\
\hline Bachelor's Degree & $79 \%$ & $75 \%$ \\
\hline Age & $20 \%$ & $22 \%$ \\
\hline Under 15-34 & $1 \%$ & $3 \%$ \\
\hline Age 35-45 & \multicolumn{2}{|l|}{} \\
\hline Age 45+ & $14 \%$ & $88.9 \%$ \\
\hline Income & $75 \%$ & $5.0 \%$ \\
\hline Middle & $5 \%$ \\
\hline High & 5 \\
\hline Housing Pattern & $4 \%$ & $95 \%$ \\
\hline $\begin{array}{l}\text { Rural (\% of rural households } \\
\text { using the Internet) }\end{array}$ \\
\hline $\begin{array}{l}\text { Urban (\% of urban households } \\
\text { using the Internet) }\end{array}$ & $96 \%$ & $76 \%$ \\
\hline Gender & $24 \%$ \\
\hline Male & $65 \%$ & \\
\hline Female & $52 \%$ & \\
\hline
\end{tabular}

Source: (TRAI, 2010), (PTA, 2011), (Ahmed \& Anoud, 2011), (ITU, 2011) 


\begin{tabular}{|c|c|}
\hline \multicolumn{2}{|c|}{ Table 4: Main online activities and reasons for having no Internet connection } \\
\hline Pakistan(As of June 2011) & India(As of December 2010) \\
\hline \multicolumn{2}{|l|}{ Main online activities (in priority order) } \\
\hline $\begin{array}{l}\text { 1) Information Search (Financial, educational, } \\
\text { general) }\end{array}$ & 1) E-mail \\
\hline 2) Email & 2) Entertainment(Music, Videos) \\
\hline 3) Playing online games & $\begin{array}{l}\text { 3) Information Search (Financial, educational, } \\
\text { general) }\end{array}$ \\
\hline 4) Entertainment (Music, Videos) & 4) Text chat \\
\hline 5) Internet telephony and videos & 5) Playing online games \\
\hline 6) Text chat & 6) Internet telephony and videos \\
\hline 7) Online Banking & 7) Online Banking \\
\hline 8) Online Reservations & 8) Online Reservations \\
\hline \multicolumn{2}{|c|}{ Reasons for having no home connection (in priority order) } \\
\hline 1) No awareness of Internet & 1) No awareness of Internet \\
\hline 2) No Need of Internet & 2) No Need of Internet \\
\hline 3) Access elsewhere & 3) Un-availability of Internet Access Point \\
\hline 4) Don't have PC know-how & 4) Don’t have PC know-how \\
\hline 5) Do not have PC & 5) Do not have PC \\
\hline 6) Concern with children & 6) Need guidance about Internet Use \\
\hline 7) Improper electricity supply & 7) Improper electricity supply \\
\hline 8) Unaffordable & 8) Unaffordable \\
\hline
\end{tabular}

Source: (TRAI, 2010), (Ahmed \& Anoud, 2011), (Sehrish Akram \& Nadia Asghar, 2012)

Table 5: Market shares (\%) for residential Broadband Internet Markets

\begin{tabular}{|l|l|l|l|}
\hline \multicolumn{2}{|l|}{ Pakistan(As of June 2011) } & \multicolumn{2}{l|}{$\begin{array}{l}\text { India(As of } \\
\text { December 2010) }\end{array}$} \\
\hline Fixed & Wireless & Fixed & Wireless \\
\hline 49.5 & 50.5 & 93 & 6.23 \\
\hline
\end{tabular}

Source: (TRAI, 2010), (PTA, 2011)

Table 6: Top 4 Broadband Internet Firms

\begin{tabular}{|l|l|l|}
\hline & Pakistan(As of June 2011) & India(As of December 2010) \\
\hline & PTCL (57\%) & BSNL (56.84\%) \\
\hline & Wateen (15\%) & MTNL (13.20\%) \\
\hline & WorldCall (10\%) & BhartiAirtel (10.22\%) \\
\hline & Wi-Tribe (9\%) & Reliance(7.72\%) \\
\hline & Qubee (3.1\%) & Hathway (1.87\%) \\
\hline & LinkDotNet (2.5\%) & You Broadband (1.41\%) \\
\hline CR4 & $91 \%$ & $88 \%$ \\
\hline
\end{tabular}

Source: (TRAI, 2010), (PTA, 2011) 


\section{References}

[1] Wolf, J. \& Zee, N., 2000.The Last Mile: Broadband and the Next Internet Revolution 1st ed., Mcgraw-Hill.

[2] Rao, B., 2001. Broadband innovation and the customer experience imperative. International Journal on Media Management, $3(2)$, pp.56-65.

[3] CNetNews, 2002. CEOs talk broadband with Cheney - CNET News. Available at: http://news.cnet.com/2100-1033-822691.html [Accessed March 25, 2012].

[4] Sprano, E. \&Zakak, A., 2000. E-COMMERCE CAPABLE: COMPETITIVE ADVANTAGE FOR COUNTRIES IN THE NEW WORLD E-CONOMY. Competitiveness Review: An International Business Journal incorporating Journal of Global Competitiveness, 10(2), pp.114-122.

[5] Albert, S. \&Flournoy, D., 2010.Think Global, Act Local.International Journal of Sociotechnology and Knowledge Development, 2(1), pp.59-79.

[6] Lee, C. \& Chan-Olmsted, S.M., 2004. Competitive advantage of broadband Internet: a comparative study between South Korea and the United States. Telecommunications Policy, 28(9-10), pp.649-677.

[7] Garfield, M.J. \& Watson, R.T., 1997. Differences in national information infrastructures: the reflection of national cultures. The Journal of Strategic Information Systems, 6(4), pp.313-337.

[8] Han, G., 2003. Broadband Adoption in the United States and Korea: Business Driven Rational Model Versus Culture Sensitive Policy Model. Trends in Communication, 11(1), pp.3-25.

[9] Hargittai, E., 1999. Weaving the Western Web: explaining differences in Internet connectivity among OECD countries.Telecommunications Policy, 23(10-11), pp.701-718.

[10] OECD, 2001a.The Development of Broadband Access in the OECD Countries, OECD Publishing. Available at: http://ideas.repec.org/p/oec/stiaab/56-en.html [Accessed May 14, 2012].

[11] OECD, 2008.Broadband Growth and Policies in OECD Countries. Available at: http://www.oecd.org/document/1/0,3343,en_2649_34223_40931201_1_1_1_1,00.html [Accessed May 24, 2012].

[12] Lee, H., O'Keefe, R.M. \& Yun, K., 2003. The Growth of Broadband and Electronic Commerce in South Korea: Contributing Factors. The Information Society, 19(1), pp.81-93.

[13] Choudrie, J. \& Lee, H., 2004. Broadband development in South Korea: institutional and cultural factors. European Journal of Information Systems, 13(2), pp.103-114.

[14] Hon, W.S., 1992. Exploiting information technology: A case study of Singapore. World Development, 20(12), pp.1817-1828.

[15] King, J.L. et al., 1994. Institutional Factors in Information Technology Innovation.Information Systems Research, 5(2), pp.139169.

[16] Cane, A., 1992. Information technology and competitive advantage: Lessons from the developed countries. World Development, 20(12), pp.1721-1736.

[17] Goodman, S. et al., 1994. The global diffusion of the Internet: patterns and problems. Commun.ACM, 37(8), pp.27-31.

[18] Bazar, B., 1997.A Preliminary Model of Internet Diffusion within Developing Countries. Available at: http://ausweb.scu.edu.au/proceedings/boalch/paper.html [Accessed May 14, 2012].

[19] Wolcott, P. et al., 2001. A Framework for Assessing the Global Diffusion of the Internet.Journal of the Association for Information Systems, 2(1). Available at: http://aisel.aisnet.org/jais/vol2/iss1/6.

[20] Beilock, R. \&Dimitrova, D.V., 2003.An exploratory model of inter-country Internet diffusion.Telecommunications Policy, 27(34), pp.237-252.

[21] Mbarika, V.W. \& Byrd, T.A., 2009. An Exploratory Study of Strategies to Improve Africa's Least Developed Economies; Telecommunications Infrastructure: The Stakeholders Speak. IEEE Transactions on Engineering Management, 56(2), pp.312328.

[22] Oxley, J.E. \&Yeung, B., 2001. E-Commerce Readiness: Institutional Environment and International Competitiveness. Journal of International Business Studies, 32(4), pp.705-723.

[23] Greenstein, S. \& Prince, J., 2006.The Diffusion of the Internet and the Geography of the Digital Divide in the United States.National Bureau of Economic Research Working Paper Series, No. 12182. Available at: http://www.nber.org/papers/w12182.

Turk, T., JermanBlažič, B. \&Trkman, P., 2008.Factors and sustainable strategies fostering the adoption of broadband communications in an enlarged European Union.Technological Forecasting and Social Change, 75(7), pp.933-951.

Czernich, N. et al., 2011. Broadband Infrastructure and Economic Growth.The Economic Journal, 121(552), pp.505-532.

[27] Dosi, G., Pavitt, K. \&Soete, L., 1990.The Economics of Technical Change and International Trade, Laboratory of Economics and Management (LEM), Sant'Anna School of Advanced Studies, Pisa, Italy. Available at: http://ideas.repec.org/b/ssa/lembks/dosietal-1990.html [Accessed May 24, 2012].

[28] Fagerberg, J., 1988. International Competitiveness.The Economic Journal, 98(391), pp.355-374.

[29] Porter, M.E., 1990a. Competitive Advantage of Nations, Free Press.

[30] Grant, R.M., 2006. Porter's "competitive advantage of nations": An assessment. Strategic Management Journal, 12(7), pp.535548 .

[31] Kaufman, A. et al., 1994. Porter's Model for Geographic Competitive Advantage: The Case of New Hampshire. Economic Development Quarterly, 8(1), pp.43-66.

[32] Rugman\& Alan, 1992. Porter takes the wrong turn. Business Quarterly, 57(36), pp.59-64.

[33] Bellak, C.J. \& Weiss, A., 1993.A note on the Austrian “diamond."Management International Review, 33(2), pp.109-118.

[34] Rugman\&D’Cruz, 1993. The "Double Diamond" Model of International Competitiveness: The Canadian Experience. , 33, pp.17-39.

[35] Cartwright, W.R., 1993. Multiple Linked "Diamonds" and the International Competitiveness of Export-Dependent Industries: The New Zealand Experience. MIR: Management International Review, 33, pp.55-70.

[36] O'Donnellan, 1994. The presence of Porter's sectoral clustering in Irish manufacturing. , 25, pp.221-231.

[37] Moon, H.C., Rugman, A.M. \&Verbeke, A., 1995.The generalized double diamond approach to international competitiveness. , Research in Global Strategic Management(5), pp.97-114.

[38] O’Malley, E. \& O'Gorman, C., 2001.Competitive Advantage in the Irish Indigenous Software Industry and the Role of Inward Foreign Direct Investment.European Planning Studies, 9(3), pp.303-321.

[39] Öz, Ö., 2002. Assessing Porter's framework for national advantage: the case of Turkey.Journal of Business Research, 55(6), pp.509-515. 
[40] Sohn, J., 2004. Do birds of a feather flock together?: Economic linkage and geographic proximity. The Annals of Regional Science, 38(1), pp.47-73.

[41] Healey, M.J. \& Dunham, P.J., 1994.Changing Competitive Advantage in a Local Economy: The Case of Coventry, 197190.Urban Studies, 31(8), pp.1279-1301.

[42] Curran, P.J., 2001. Competition in UK Higher Education: Applying Porter's diamond model to Geography departments. Studies in Higher Education, 26(2), pp.223-251.

[43] Chobanyan, A. \& Leigh, L., 2006. The competitive advantages of nations: Applying the "Diamond" model to Armenia. International Journal of Emerging Markets, 1(2), pp.147-164.

[44] Chang, S.-C., 2005. The TFT-LCD industry in Taiwan: competitive advantages and future developments. Technology in Society, 27(2), pp.199-215.

[45] Wonglimpiyarat, J., 2005. What are the mechanisms driving the success of the US Silicon Valley? International Journal of Technology, Policy and Management, 5(2), pp.200 - 213.

[46] Wonglimpiyarat, J., 2006. The dynamic economic engine at Silicon Valley and US Government programmes in financing innovations. Technovation, 26(9), pp.1081-1089.

[47] Wu, D., 2006. Analyzing China's automobile industry competitiveness through Porter's diamond model, Lethbridge, Alta.: University of Lethbridge, Faculty of Management, 2006. Available at: https://www.uleth.ca/dspace/handle/10133/583 [Accessed May 15, 2012].

[48] Williams, M. et al., 2010. What Role Should Governments Play in Broadband Development? In ICTs for Development. OECD Publishing, pp. 119-137. Available at: http://www.oecd-ilibrary.org/development/icts-for-development/what-role-shouldgovernments-play-in-broadband-development_9789264077409-6-en [Accessed May 26, 2012].

[49] Picot, A. \&Wernick, C., 2007.The role of government in broadband access.Telecommunications Policy, 31(10-11), pp.660-674.

[50] Bradshaw, Y. \& Wallace, M., 1991. Informing Generality and Explaining Uniqueness: The Place of Case Studies in Comparative Research. International Journal of Comparative Sociology, 32(1-2), pp.154-171.

[51] Yin, R.K., 1992.The Case Study Method as a Tool for Doing Evaluation.Current Sociology, 40(1), pp.121-137.

[52] Winston Tellis, 1997. Introduction to Case Study.The Qualitative Report, Volume 3, Number 2. Available at: http://www.nova.edu/ssss/QR/QR3-2/tellis1.html [Accessed May 26, 2012].

[53] Yin, D.R.K., 2002.Applications of Case Study Research Second Edition 2nd ed., Sage Publications, Inc.

[54] Gomm, R., Hammersley, M. \& Foster, P. eds., 2000.Case Study Method: Key Issues, Key Texts annotated ed., Sage Publications Ltd.

[55] Dul, J. \&Hak, T., 2007.Case Study Methodology in Business Research, Butterworth-Heinemann.

[56] O'Shaughnessy, N.J., 1996. Michael Porter's revisited. Management Decision, 34(6), pp.12-20.

[57] Beije, P.R. \& Nuys, H.O. eds., 1995.The Dutch Diamond: The Usefulness of Porter in Analyzing Small Countries, GarantUitgevers N V.

[58] Guillén, M.F. \&Suárez, S.L., 2001.Developing the Internet: entrepreneurship and public policy in Ireland, Singapore, Argentina, and Spain.Telecommunications Policy, 25(5), pp.349-371.

[59] Wunnava, P.V. \&Leiter, D.B., 2009.Determinants of Intercountry Internet Diffusion Rates.American Journal of Economics and Sociology, 68(2), pp.413-426.

[60] Atkinson, R.D. \& Court, R.H., 1998.The New Economy Index: Understanding America's Economic Transformation, Progressive Policy Institute.

[61] OECD, 2001b.OECD Economic Outlook, Volume 2001 Issue 1. Available at: http://www.oecd-ilibrary.org/economics/oecdeconomic-outlook-volume-2001-issue-1_eco_outlook-v2001-1-en [Accessed May 26, 2012].

[62] OECD, 2001c. OECD Reviews of Regulatory Reform: Regulatory Reform in Korea 2000. Available at: http://www.oecdilibrary.org/fr/governance/oecd-reviews-of-regulatory-reform-regulatory-reform-in-korea-2000_9789264181748-en [Accessed May 26, 2012].

[62] US Census Bureau, 2001.Measuring Electronic Business. Available at: http://www.census.gov/econ/estats/archives.html [Accessed May 26, 2012].

[63] PTA. (2011). PTA Annual Report 2011. Retrieved May 25, 2012, from http://www.pta.gov.pk/index.php?option=com_content $\&$ view=article\&id=361\&Itemid=590

[64] ABI Research, 2012.Indian Broadband Subscriber Base to Top 15 Million in 2012. Available at: http://www.abiresearch.com/press/3848-Indian+Broadband+Subscriber+Base+to+Top+15+Million+in+2012 [Accessed May 17, 2012].

[65] TimesofIndia, 2012.Trai's proposal can lead to hike in mobile tariff: Uninor - The Times of India. Available at: http://timesofindia.indiatimes.com/tech/news/telecom/Trais-proposal-can-lead-to-hike-in-mobile-tariffUninor/articleshow/13163405.cms [Accessed May 17, 2012].

[66] TRAI. (2010). Recommendation on National Broadband Plan. Retrieved May 25, 2012, from http://www.trai.gov.in/Content/RecommendationDescription.aspx?RECOMEND_ID=360\&qid=11

[67] Informationweek, 2011. Government of India shares plans to increase broadband penetration. Available at: http://www.informationweek.in/Government/11-12-

14/Government_of_India_shares_plans_to_increase_broadband_penetration.aspx [Accessed May 17, 2012].

[68] BusinessWire.com, 2011. A 2011 India Telecoms, Mobile, Broadband and Forecasts Report: India Continues to be One of the Fastest and Largest Growing Major Telecom Markets in the World | Business Wire. Available at: http://www.businesswire.com/news/home/20110715005047/en/Research-Markets-2011-India-Telecoms-Mobile-Broadband [Accessed May 17, 2012].

[69] Ahmed, M. \&Anoud, 2011.Effects of Various Cultural Attributes on Web Browsing Behavior of Developing Countries' Online Community., 2(1).

[70] BimalAnjum\& Rajesh Tiwari, 2011.Economic and Social Impacts of E-Commerce.International Journal of Computing and Corporate Research. Available at: http://www.ijccr.com/November2011/9.pdf [Accessed June 1, 2012].

[71] Brown, D.H. \& Thompson, S., 2011. Priorities, policies and practice of e-government in a developing country context: ICT infrastructure and diffusion in Jamaica. European Journal of Information Systems, 20(3), pp.329-342.

[72] CnetNews, 2006. Pakistan plans largest mobile WiMax rollout - CNET News. CNET. Available at: http://news.cnet.com/21001039_3-6075684.html [Accessed May 27, 2012].

[73] Gao, P. \&Rafiq, A., 2009. The transformation of the mobile telecommunications industry in Pakistan: A developing country perspective. Telecommunications Policy, 33(5-6), pp.309-323. 
[74] Gulati, G.J., Yates, D.J. \& Williams, C.B., 2012.Understanding the Impact of Political Structure, Governance and Public Policy on E-Government.In System Science (HICSS), 2012 45th Hawaii International Conference on.pp. 2541 -2550.

[75] ITU, 2011.ITU statistics. Available at: http://www.itu.int//TU-D/ict/statistics/ [Accessed May 25, 2012].

[76] OECD, 2002.E-commerce Intensity.In Information Technology Outlook 2002. OECD Publishing, pp. 129-156. Available at: http://www.oecd-ilibrary.org/science-and-technology/information-technology-outlook-2002/e-commerce-intensity_it_outlook2002-6-en [Accessed May 26, 2012].

[77] Porter, M., 1990b.The Competitive Advantage of Nations.Harvard Business Review. Available at: http://hbr.org/1990/03/thecompetitive-advantage-of-nations/ar/1 [Accessed May 26, 2012].

[78] SehrishAkram\& Nadia Asghar, 2012. An empirical analysis of Customer satisfaction on adoption of internet Banking in Pakistan. Interdisciplinary Journal of Contemporary Research in Business. Available at: http://ijcrb.webs.com/archives.htm [Accessed June 2, 2012].

[79] Seyal, A.H. et al., 2004. Determinants of Electronic Commerce in Pakistan: Preliminary Evidence from Small and Medium Enterprises. Electronic Markets, 14(4), pp.372-387.

[80] Sulaiman\&Mohezar, S., 2007. A Trust Model for E-Commerce in Pakistan: An Empirical Research. Asian journal of information, 6(2), pp.192-199.

[81] The Economist, 2009. Idea: E-commerce. The Economist. Available at: http://www.economist.com/node/14298940 [Accessed May 25, 2012].

[82] UNDP, 2011. Human Development Reports (HDR). Available at: http://hdr.undp.org/en/statistics/ [Accessed May 25, 2012].

[83] UNSECO STATISTICS, 2011.UNESCO Institute for Statistics. Available at: http://www.uis.unesco.org/Pages/default.aspx [Accessed May 25, 2012].

[84] World Bank, 2011a.World Development Indiactors, 2011. Available at: http://data.worldbank.org/data-catalog/worlddevelopment-indicators/wdi-2011 [Accessed May 25, 2012].

[85] World Bank, 2011b.Information and Communication (ICT) At-a-Glance. Available at: http://data.worldbank.org/datacatalog/ICT-table [Accessed May 25, 2012].

[86] World Economic Forum, 2011. The Global Information Technology Report 2010-2011. The Global Information Technology Report 2010-2011 | World Economic Forum. Available at: http://www.weforum.org/reports/global-information-technologyreport-2010-2011-0 [Accessed May 25, 2012]. 